\title{
An Overview on Atomization and Its Drug Delivery and Biomedical Applications
}

\author{
Anu Mohandas ${ }^{1}\left(\mathbb{D}\right.$, Hongrong Luo $^{2} \mathbb{D}$ and Seeram Ramakrishna ${ }^{1, * \mathbb{D}}$ \\ 1 Center for Nanotechnology \& Sustainability, Department of Mechanical Engineering, \\ National University of Singapore, Singapore 117581, Singapore; anumohandas031@gmail.com \\ 2 Engineering Research Center in Biomaterials, Sichuan University, Chengdu 610064, China; hluo@scu.edu.cn \\ * Correspondence: seeram@nus.edu.sg
}

Citation: Mohandas, A.; Luo, H.; Ramakrishna, S. An Overview on Atomization and Its Drug Delivery and Biomedical Applications. Appl. Sci. 2021, 11, 5173. https://doi.org/ 10.3390/app11115173

Academic Editor: Ipsita Banerjee

Received: 8 April 2021

Accepted: 31 May 2021

Published: 2 June 2021

Publisher's Note: MDPI stays neutral with regard to jurisdictional claims in published maps and institutional affiliations.

Copyright: (c) 2021 by the authors. Licensee MDPI, Basel, Switzerland. This article is an open access article distributed under the terms and conditions of the Creative Commons Attribution (CC BY) license (https:// creativecommons.org/licenses/by/ $4.0 /)$.

\begin{abstract}
Atomization is an intricate operation involving unstable and complex networks with rupture and fusion of liquid molecules. There are diverse details that typify the spray formation, which are the technique and configuration of the atomization process, dimension and structure of the nozzle, experimental parameters, etc. Ultimately, the process generates fine sprays from the bulk of a liquid. Some examples of atomization that we come across in our day-to-day life are antiperspirant or hair spray, shower head, garden sprinkler, or cologne mist. In this review paper we are briefly discussing the theoretical steps taking place in an atomization technique. The instabilities of the jet and sheet are explained to understand the underlying theory that breaks the jet or sheet into droplets. Different types of atomization processes based on the energy sources are also summarized to give an idea about the advantages and disadvantages of these techniques. We are also discussing the various biomedical applications of the electrohydrodynamic atomization and its potential to use as a drug delivery system. In short, this paper is trying to demonstrate the diverse applications of atomization to show its potency as a user friendly and cost-effective technique for various purposes.
\end{abstract}

Keywords: atomization; primary atomization; secondary atomization; drop size; mathematical formulations; drug delivery; electrospray; biomedical applications

\section{Introduction}

The process of the destruction of feed liquid into drops or fine spray by the influence of surface tension together with interior or exterior forces is referred to as atomization. When there is no influence of disturbances, the surface tension of the liquid will pull it into a sphere-shape in which the surface energy is less. When it is disturbed with other forces, the surface tension will result in instability that leads to the destruction of feed liquid (thin ligaments or sheets of liquid) into smaller drops [1]. Some examples of atomization that we come across in our day-to-day life are antiperspirant or hair spray, shower head, garden sprinkler, cologne mist, etc. The outcome of the atomization process is to generate spray, which is a gathering of fluid beads that are in an organized motion and each sphere-shaped drop is also known as a particle [2]. Thus, to generate particles of preferred thinness, the measure of the external force or any kind of force that causes disruption, should either level or top the force applied by the surface tension of the particular fluid [1]. There are factors that affect the atomization process and its result of the fine spray of liquid droplets. One of the major factors is the properties of the fluid that is being used in the process and those are surface tension, density and viscosity of the fluid. All the three have a similar effect, that is the higher these properties, the larger the droplets. Another factor that can affect this is the temperature at which atomization is taking place. The temperature has an inversely proportional effect on surface tension of the fluid, i.e., higher temperature reduces the surface tension of the fluid and thus affects the droplet size [2].

Recently scientists are exploring the utilization of atomization in various biomedical applications. One crucial challenge associated with biomedical implantations are infec- 
tions caused by biofilm formation on the implanted biomaterial [3]. Micro or nano level modification of the implant surface is one of the remedies. Atomization techniques like electrospraying are used to modify the biomaterials to generate drug distributing transporters, embellished microarrays, implant coatings, effective scaffolds for tissue engineering, oral vaccine delivery etc. for various biological applications [4-6]. The various biomedical applications of atomization are briefly discussed in the later section.

\subsection{Stagnant Drop Formation}

This is achieved when liquid is flowing out in a very deliberate ratio along a disturbance and is explained as a quasi-steady illustration of a droopy or suspended drop. When the gravitational pull overpowers the surface tension of the liquid, the liquid is dragged away from the barrier as a drop. The researchers have already found the equations to calculate the diameter of the drops generated and it was found that the size of the drops produced at a low flow rate are much larger than the opening of the barrier, which is not applicable for the production of fine sprays. Thus, gravitational force is not considerable or even insignificant in atomization as the diameter of the drop decreases. It is also noted that, as the flow rate of the liquid is increased then the droplet formation is not explained by quasi-steady force equilibrium but by the resistance of the liquid and its dynamics [1].

\subsection{Dynamic Drop Formation}

This is the phenomena that is explained in almost all atomization processes. In this the liquid is flowing at a definite flow rate to cause an uninterrupted stream of droplets. Researchers did a study to understand the mechanism of atomization and explained two mechanisms which are superficial interruption of thin waves at the exterior of the liquid and cavitation [7]. Later, the observations concluded that atomization is a result of the combination of these two mechanisms [8,9]. The series of steps involved in atomization are [1]:

- The liquid is allowed to flow through a nozzle to accelerate its velocity to a required level causing the liquid to lengthen into jets or sheets;

- Liquid surface is initiated with external or internal disturbances like pressure, airflow, waves, etc.;

- Short liquid ligaments are shaped on the surface as a result of these disturbances;

- The surface tension of the liquid causes the ligaments to break into small droplets;

- These droplets will be further broken down into fine and uniform drops as they travel across the gassy channel.

Figure 1 represents the schematic of the atomization process. The atomization process is ordered into three stages: the first stage is the liquid ligament development on the surface, the second stage is the breakdown of the ligaments into droplets and third stage is the added breakdown of the droplets into small drops.

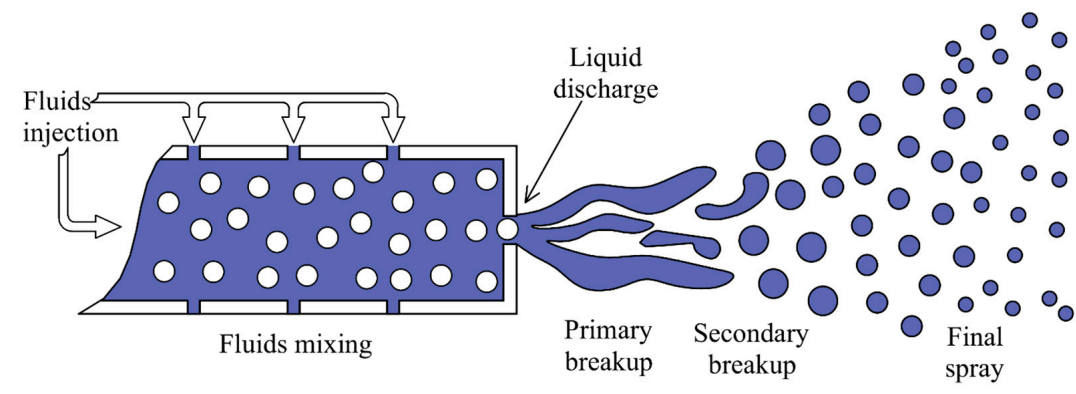

Figure 1. Schematic presentation of atomization; reproduced from [10].

\subsection{General Theory}

In this division we are considering the physical techniques involved in the atomization process. 


\subsubsection{Primary Atomization}

It is defined as the process involving the initiation of liquid ligament and globules of liquid from the bulk of the fluid. It also explains the route of spray establishment considering the jet injection appliances, injection settings and superficial kinetics. The first step in primary atomization is the injection of the fluid through a small orifice (nozzle) to generate ligaments and this takes place as a result of a balance in distinctive features of the vapor-liquid scheme and other forces acting on it. The quality of the atomizer used in atomization will also decide the nature of the initial process [11]. In 1878, Rayleigh described that surface tension of the fluid is the leading force acting on the process. When the velocity of the liquid in the jet is amplified, it creates an unstable swirl inside. These swirls result in the shear breakup of the liquid and this is known as Rayleigh breakup [12]. Another group of scientists detailed the atomization process of two or more liquid jets sharing a common axis, atomized by a fast-flowing gas in the same direction [13]. Faeth did a study on columns of liquid and the gas medium in which both are flowing oppositely and observed that liquid medium exhibits disturbances that proceed to the process of breaking up of droplets. He explained that when the Weber number (proportion of the force applied by air on liquid to surface tension of liquid) is sufficiently small, the breakup of the liquid column governs [14].

The modelling proposals are acquired from linear steady review, which considers that, initially the sheet of liquid is sustained and this demonstrates the wavelength of the unstable wave like pattern in the liquid sheet (Figure 2). This wavelength plays a remarkable role during the initial stage of atomization, in anticipating the size of the ligaments and the droplets [11].

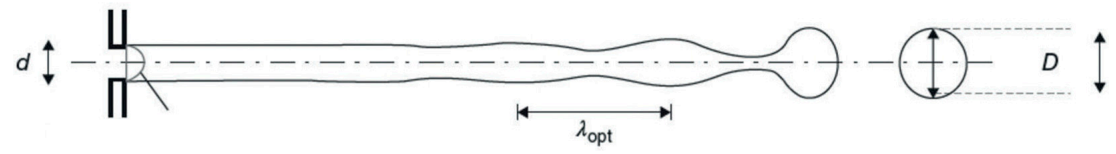

Figure 2. Schematic representation of the wave and its wavelength, d-Initial diameter of the jet; $\lambda_{\mathrm{opt}}$-Optimum wavelength; reproduced from [15].

\subsubsection{Secondary Atomization}

The droplets generated after primary atomization will be further atomized into fine drops and this is achieved by secondary atomization. When there is an increase in the relative motion between liquid droplet and the encircling gas, the droplets will be further broken down and this is explained by three breakup systems: bag breakup, stretchingthinning breakup and catastrophic breakup (briefed in Table 1) [16]. Weber number (We) is considered as the commanding factor for the liquids that have a low viscosity [11].

Table 1. Different types of breakup systems experiencing in secondary atomization.

\begin{tabular}{ccl}
\hline Breakup Systems & Weber Number Range & \multicolumn{1}{c}{ Description } \\
\hline Bag breakup & $12-80$ & $\begin{array}{l}\text { The region at which there is no movement in a droplet will be } \\
\text { puffed out into a narrow void (bag) which is anchored at the } \\
\text { middle; holes will be developed in this void that shrink and } \\
\text { split into small drops }\end{array}$ \\
\hline $\begin{array}{c}\text { Stretching-thinning } \\
\text { breakup }\end{array}$ & $\begin{array}{l}\text { The droplets are flattened and stretched and the middle of } \\
\text { these stretched droplets are strained into thin stream by the } \\
\text { force exerted on liquid by the air; this stream split into thin } \\
\text { ligaments which breaks into small drops }\end{array}$ \\
\hline $\begin{array}{c}\text { Catastrophic } \\
\text { breakup }\end{array}$ & $\begin{array}{l}\text { Same as stretching-thinning system; the edges of the droplets } \\
\text { are strained into thin liquid stream by the force of high } \\
\text { velocity air; also causes surface instabilities and then breaks } \\
\text { up into fine jet of drops }\end{array}$ \\
\hline [21,22]
\end{tabular}




\section{Kinetics of Liquid Jets and Sheets}

Atomization is an intricate operation involving unstable and complex networks with rupture and fusion of liquid molecules. There are diverse details that typify the spray formation, which are the technique and configuration of the atomization process, dimension and structure of the nozzle, experimental parameters, etc. [23]. Even though there are literature surveys on various atomization processes [24-27], the complexity of the technique, the possession of the atomizer on the droplet qualities, imprecision in computation strategies are still not well understood [28,29]. Atomization occurs when the liquid is imposed through an opening to generate spray. The type of nozzle and the pressure determines whether a jet or sheet is obtained before atomization. Since, there is liquid jet or sheet; instability of liquid jet and liquid sheet are considered for the formation of the droplets. These theories are also used to study the growth of perturbation waves, which is used to understand atomization to generate drops by the breakup of these liquid jets and liquid sheets [30].

\subsection{Instability of Liquid Jets}

The liquid jet originated from the nozzle comes in contact with the surrounding gas, and this jet is broken down into drops when put through interferences like pressure variation, surface shift, velocity change of the apparatus or the liquid jet and also variations in temperature, consistency of the liquid and feature of the liquid surface to endure superficial exertion [31-33]. These interferences cause instability in the liquid jet causing disturbance waves in it and the instability is characterized by studying the development of this wave, droplet emergence and rupture length of the jet [34,35]. The pressure variation is obtained by using acoustic waves, change in velocity is obtained by vibrating the flow, temperature is varied by providing regular heating and the surface is disturbed by using an electrifying sensor [30]. Rayleigh studied the vulnerability of the liquid jet and he procured an equation to calculate the growth rate of the disturbances that cause instability in the jet. He also hypothesized that interruptions with the highest advancing rate will cause dispersion of the jet into the droplet and the size of this droplet was calculated in the series of wavelengths of the interruptions [12].

Studies on instability of a liquid jet reveal that a required wavenumber is necessary to generate stable liquid jet and when the wavenumber is less than the required value, it generates an unstable jet leading the breakup of the jet into a large droplet and one or more small drops. Figure 3 represents such a breakup of the liquid jet. By adjusting the interferences, we can generate droplets without the small drops (satellites).

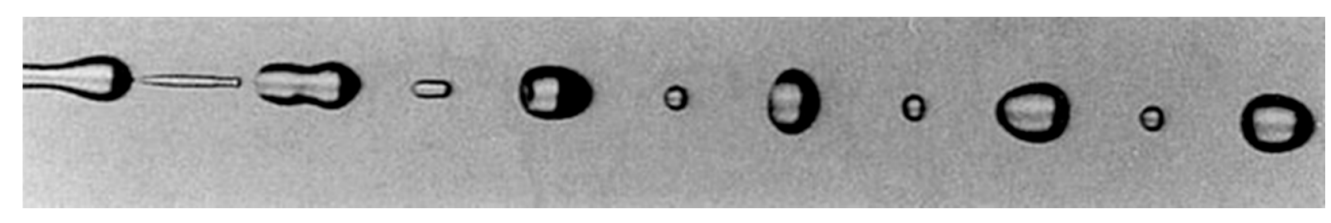

Figure 3. Instability of liquid jet with satellite drops; reproduced with permission from [36].

Later in 1931, Weber introduced the effect of viscosity in the exploration of jet split-up using the 3D partial differential equations of Newtonian viscous fluid and found that viscosity of the fluid plays a role in slowing down the growth rate of the interference and thus elongating the wavelength, without altering the wavenumber [37]. Similarly, Bogy [38] and Sirignano et al. [39] are the two other groups of scientists who provided the theoretical examination of the instability of the liquid jet.

\subsection{Mechanism of Liquid Sheet Instability}

Like liquid jets, in some cases liquid sheets originate from the nozzle and this sheet will be split into small ligaments through oscillations. The ligaments are then broken into 
small droplets to form a fine spray. The size of the droplets in this spray will directly depend on the thickness of the liquid sheet that initially originated [30].

The instability of the liquid sheet can be studied by relating to time and space occupied and there are many literatures explaining the mechanism of instability [40-42]. Dombrowski et al. were the group of scientists who studied the impact of various factors in fracturing the liquid sheet into droplets and they realized that the liquid sheets with an elevated velocity are encountering a wave motion [43-45]. In 1999, Senecal et al. studied the mechanism of instability of a viscous fluid sheet in gas and established two well-defined systems for the atomization of the liquid sheet. One system is with a very low Weber number, the liquid sheet is disrupted by long waves and in this case the viscosity of the liquid is not considered. In another system with higher Weber number, the film is disrupted with short waves and in this case the viscosity of the fluid plays a role in the dispersion of the film into droplets [46].

\section{Atomization Processes}

Table 2 briefly describes the different types of atomization processes and its characteristics.

Table 2. Different atomization processes and its characteristics; Based on [1,2,15,47-51].

\begin{tabular}{|c|c|c|c|c|c|}
\hline Types & Energy Source & Mechanism & Class of Spray & Advantages & Disadvantages \\
\hline Hydraulic & Fluid pressure & $\begin{array}{l}\text { Pressure exerted on the fluid } \\
\text { drives it through the nozzle to } \\
\text { generate fluid sheets with } \\
\text { high velocity and leading its } \\
\text { disruption to fragments and } \\
\text { then to droplets by friction } \\
\text { between liquid and air }\end{array}$ & $\begin{array}{l}\text { Non-uniform, } \\
\text { rough }\end{array}$ & $\begin{array}{l}\text { Economical, utilize } \\
\text { small rooms for } \\
\text { drying }\end{array}$ & $\begin{array}{l}\text { Not relevent for } \\
\text { viscous fluids, } \\
\text { wide range of } \\
\text { droplet size } \\
\text { dispersion }\end{array}$ \\
\hline Pneumatic & Air pressure & $\begin{array}{l}\text { Fluid at low velocity passing } \\
\text { through the nozzle is } \\
\text { surrounded by high velocity } \\
\text { flow of air, boosting friction } \\
\text { between two medium causing } \\
\text { disruption of fluid sheet }\end{array}$ & $\begin{array}{l}\text { Heterogenous, } \\
\text { average roughness }\end{array}$ & $\begin{array}{l}\text { Uniform droplets, } \\
\text { applicable for } \\
\text { viscous fluids, } \\
\text { superior } \\
\text { productivity }\end{array}$ & $\begin{array}{c}\text { Expensive, ensuing } \\
\text { instability }\end{array}$ \\
\hline Rotary & Centrifugal force & $\begin{array}{l}\text { Atomizer has a spinning disc } \\
\text { at the center to which the fluid } \\
\text { is introduced through the } \\
\text { nozzle; centrifugal force takes } \\
\text { the fluid to the margin of the } \\
\text { disc and flip off the boundary } \\
\text { setting up ligaments that then } \\
\text { breaks into droplets }\end{array}$ & Heterogenous & $\begin{array}{l}\text { Uniform droplets, } \\
\text { no clogging of } \\
\text { atomizer, superior } \\
\text { productivity }\end{array}$ & $\begin{array}{l}\text { Expensive, not } \\
\text { relevant for } \\
\text { viscous fluids, } \\
\text { requires larger } \\
\text { rooms for drying }\end{array}$ \\
\hline Electrostatic & Electric charge & $\begin{array}{l}\text { An electric field applied } \\
\text { between atomizer and } \\
\text { workpiece to make it } \\
\text { conductive; fluid passed } \\
\text { through the electric field and } \\
\text { the repulsive force disrupt the } \\
\text { fluid into droplets and is } \\
\text { gathered at the workpiece }\end{array}$ & Finer, homogenous & $\begin{array}{l}\text { Fine \& uniform } \\
\text { droplets, no } \\
\text { clogging of } \\
\text { atomizer }\end{array}$ & $\begin{array}{l}\text { Varying film } \\
\text { thickness due to } \\
\text { diverse } \\
\text { electrostatic } \\
\text { excitation in the } \\
\text { core \& shell of } \\
\text { the system }\end{array}$ \\
\hline Ultrasonic & $\begin{array}{c}\text { Electromechanical } \\
\text { device }\end{array}$ & $\begin{array}{l}\text { Fluid is passed through a } \\
\text { vibrating electromechanical } \\
\text { device causing the disruption } \\
\text { of the fluid into droplets }\end{array}$ & $\begin{array}{l}\text { Very fine and } \\
\text { homogenous }\end{array}$ & $\begin{array}{l}\text { Control spray size } \\
\text { by altering the } \\
\text { vibrational } \\
\text { frequency }\end{array}$ & $\begin{array}{l}\text { Not relevant for } \\
\text { viscous fluids, } \\
\text { restriction in } \\
\text { scaling up of } \\
\text { the system }\end{array}$ \\
\hline
\end{tabular}

Figure 4 represents the different types of commercially used atomizers, the device used for the atomization process to develop atomized sprays for various applications. 


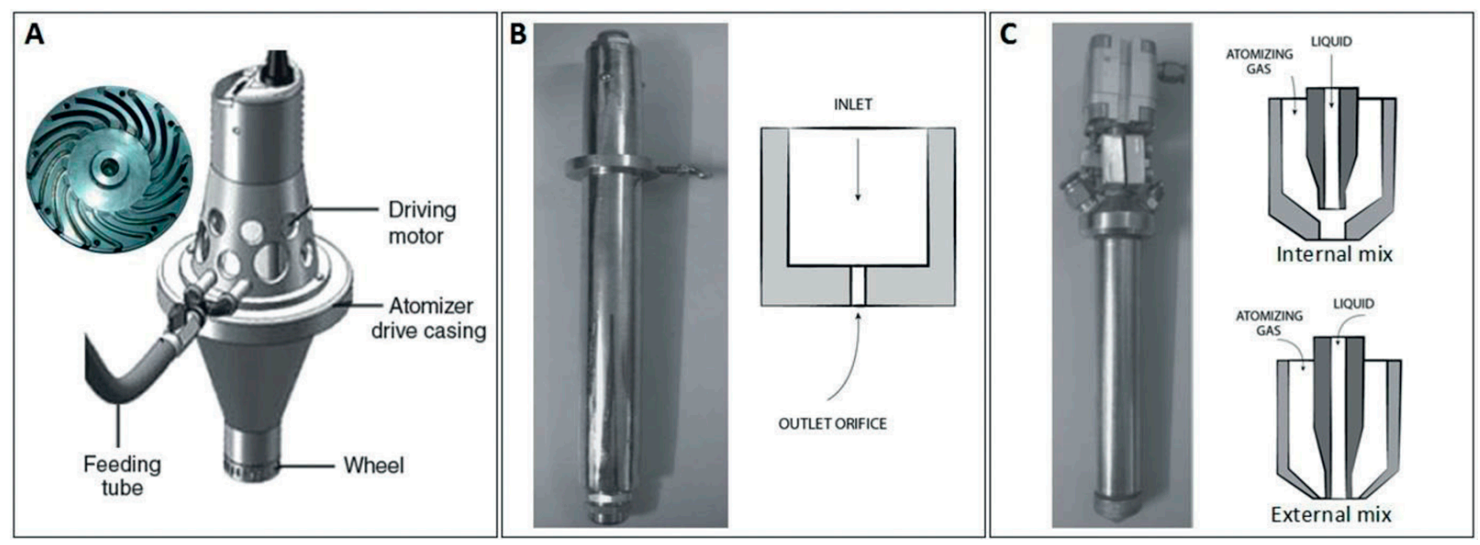

Figure 4. Schematic representation of atomizers used in: (A) rotary atomization, (B) hydraulic atomization and (C) pneumatic atomization; reproduced from [15].

\section{Drop Size and Distribution in Spray}

Sprays are generated by the disruption of liquid jet or sheet and it consists of a number of droplets. The characteristics of these droplets depends on various factors. Spraying is a technique used in different applications like drug delivery, agriculture, painting, etc., and for each application the size of the drops vary to provide efficiency [52]. For example, while spraying pesticides in an agricultural field, the size of the drops in the spray should be small for adequate deposition and safeguard [53]. Similarly for drug distribution, the drops should be small enough to easily inhale the spray and at the same time it should not be very small so that the drug evaporates before inhalation [54-56].

Dombrowski et al. [43] were the first group of scientists who studied the various factors influencing the formation of a liquid sheet and later the disruption of this sheet into droplets. These factors include the properties of the fluid used (surface tension and viscosity) and the physical factors applied in the system (turbulence and pressure). They explained that when the liquid sheet projected from the nozzle comes in contact with the gas, friction between the two medium causes a wave pattern on the exterior of the sheet, which is then broken down to droplets. In 1953 Squire studied the instability of a moving liquid film and observed a wave pattern on the surface of the film. He found that these waves were extending in magnitude to vary the thickness of the film (thinning) leading to the rupture of the film into fragments of Squire wavelength. These fragments will eventually form ligaments and then split into droplets [57]. There are different methods for modelling the droplet size and its distribution in a spray. One is the supreme entropy method which examines the surface tension of the fluid and its mass in calculating the diameter of the drop, but the limitation is that there is a detachment between the data obtained and the observed parameters. The discrete probability function model utilizes the straight and lateral rupture models by considering the physical factors like instability and swirl effect in the fluids and the limitation is that it cannot be used for studying the secondary atomization process. Another model is the empirical model in which an empirical curve is utilized to study the fit of the experimental data to the curve but the drawback is that it cannot be considered with a different atomization apparatus design. Several computational methods like Direct Numerical Simulations and Large Eddy Simulations are also reviewed for studying the numerical simulation of the atomization process but these methods are costly, less accessible compared to other techniques. The most accepted model for understanding the atomization process is the integral form of the conservative equations which can be later compared with the experimental values procured [58,59].

Chen et al. studied the characteristics of a droplet and its size distribution using a collaborative atomization procedure. They designed a new two-fluid vent for characterising the size and distribution of the drop with two atomizing nuclei. The numerical measurements of these droplets were done using the phase Doppler particle analyser. The 
results showed that the characteristics of the spray and its size distribution is related to the initial and incidental atomization which depended on the structure of the atomizing nucleus and the fraction of mass drift rate of gas to liquid (GLR). They also compared the newly designed vent with the standard vent and found a decrease in the diameter of droplet by $33.97 \%$ from the new vent and an increase in size distribution and velocity. The study was done by varying the mass flux of the gas and maintaining a sustained flux rate of the feed liquid, i.e., they derived a varying GLR ratio from $2.0 \%$ to $4.3 \%$. They observed that the twin fluid nozzle delivered higher energy to the droplets when the GLR ratio is high and this gave an upgraded features of the atomization process, which was the opposite when the GLR ratio was smaller. In short the structural features of the nozzle/vent like the compact throat and departure diameter, average extent between liquid stream and atomizing nucleus, all play an important role in optimizing the droplet size and its distribution. They concluded that as the GLR value is increased, this can intensify both the primary and secondary atomization by providing an upgraded features of the atomization process and with lesser impact of the constructional variables of the twin fluid nozzle on the droplet dimension and its size dispersal [58].

Microencapsulated drug delivery systems are widely used in the field of pharmaceutics and it can be generated by the ultrasonic atomization method. The size of these microdroplets play a major role in the efficiency of the drug delivery system, so it is necessary to optimise the size of these particles. Dalmoro et al. studied the relation of experimental variables and the properties of the substances used in the development of microencapsulated drug delivery systems with the size of the droplets. The size of the droplets were predicted by using three pragmatic associations that contemplate the properties of the bulk fluid and the experimental variables. Off the three relations, two were found definitive for calculating the droplet size [60]. Similarly, Poozesh and his group studied the atomization in a two-fluid vent to develop investigational and numerical tools to calculate the size and dispersal of the atomized drops. They conducted the experimental conclusion using three different feed liquids, which are water, methanol and acetone, as the fluid properties are different for all the three fluids. They compared the experimental results with the mathematical correlations to understand how much the experimental data is deviating from the theoretical explanation. They explained the data using the Sauter Mean Diameter measurements and found that the two main factors that influence the size of the droplets are the two dimensionless numbers that is the Weber number and the GLR ratio [59]. Kooij et al. in 2017, varied the experimental and fluid specifications to characterize the droplets and found that the size of the atomized drops can be calculated from Weber number (obtained from relation between stagnation and surface tension of the liquid) and the profile of the nozzle used in the atomization process [48]. Thus, the major factors influencing the size and distribution of the droplets in an atomization process are the parameters governing the experimental apparatus and the bulk liquid.

\section{Mathematical Formulations}

To begin with, the most straightforward description of atomization is the quasi-static state equilibrium of a suspended drop. As explained in Section 1.1, when the gravitational pull overpowers the surface tension of the liquid, the liquid is dragged away from the barrier as a drop. By associating surface tension $(\sigma)$ and gravitational force $(g)$, we can calculate the mass of the drop $\left(m_{D}\right)$ discharged from the orifice with a diameter $d_{o}$ [24].

$$
\mathrm{m}_{\mathrm{D}}=\left(\pi \mathrm{d}_{\mathrm{o}} \sigma\right) / \mathrm{g}
$$

From Equation (1), the diameter of the drop (D) can be calculated and it is identified as

$$
\mathrm{D}=\left\{6 \mathrm{~d}_{\mathrm{o}} \sigma / \rho_{\mathrm{L}} \mathrm{g}\right\}^{1 / 3}
$$

where $\rho_{\mathrm{L}}$ is the density of the liquid. 
Based on Equation (2), when the diameter of the orifice is reduced, the diameter of the drop generated is also reduced [24]. Another equation derived for calculating the diameter of the drop generated from a liquid film where both gravity and flow rate of the liquid comes in play is

$$
\mathrm{D}=3.3\left\{\sigma / \rho_{\mathrm{Lg}}\right\}^{0.5}
$$

It is observed that Equation (3) is suitable when the flow rate of the liquid is low, which gives a larger drop size but this is unprofessional for experimental applications as we prefer fine droplets, where the effect of gravitational force will be negligible for the drops ranging in size from 1-300 $\mu \mathrm{m}$ [24]. When the diameter of the orifice is minimized to $1 \mu \mathrm{m}$, the diameter of the drop speculated will be one tenth as sizable [1].

When the aerodynamic force comes into play during atomization that is the liquid flowing out of the orifice when it comes in contact with the neighbouring air, there will be a pressure variation that causes changes in the pressure dispersal surrounding a drop. This can lead to either an equilibrium state linking the aerodynamic force and the interior impact (from surface tension and density of the liquid) or additional distortion of the drop into droplets [24]. At equilibrium, the internal pressure $\left(\mathrm{p}_{\mathrm{I}}\right)$ of the drop is considered as a sum of the aerodynamic pressure $\left(\mathrm{p}_{\mathrm{A}}\right)$ and pressure applied by the surface tension of the liquid $\left(\mathrm{p}_{\sigma}\right)$.

$$
\mathrm{p}_{\mathrm{I}}=\mathrm{p}_{\mathrm{A}}+\mathrm{p}_{\sigma}=\mathrm{constant}
$$

For a globular-shaped drop $\mathrm{p}_{\sigma}$ is given by,

$$
\mathrm{p}_{\sigma}=4 \sigma / \mathrm{D}
$$

From the above equations it is clear that, if the pressure exerted by the surrounding air can be counteracted by the pressure applied by surface tension then the drop will remain stable without further deformation. When this equilibrium is disturbed that is the pressure of the air is higher than the pressure exerted by the surface tension of the liquid, the drop will be further disrupted into smaller drops [24].

\subsection{Disruption of Liquid Jet}

The theoretical study on liquid jet was first done by Rayleigh by considering streamline flow of liquid jet from a round aperture and suggested that when the accelerated expanding disruption reaches an optimum wavelength of $\lambda_{\text {opt }}=4.51 \mathrm{~d}$, the small-scale disruptions will cause breakup of the jet into drops [12], which is represented below in Equation (6).

$$
4.51 \mathrm{~d} \times\left(\frac{\pi}{4}\right) \mathrm{d}^{2}=\left(\frac{\pi}{6}\right) \mathrm{D}^{3}
$$

where, $\mathrm{d}$ is early jet diameter and $\mathrm{D}$ is diameter of the drop.

From Equation (6) the diameter of the drop is obtained as

$$
\mathrm{D}=1.89 \mathrm{~d}
$$

The limitation in Rayleigh's study was that he considered the variables surface tension of the liquid and forces acting at rest, neglecting the viscosity of the feed liquid and the aerodynamic forces. Later, Weber included the effect of surrounding air into Rayleigh's study and found that the optimum wavelength reduces when the aerodynamic forces comes into play and found it to be $\lambda_{\mathrm{opt}}=2.8 \mathrm{~d}$ resulting in a smaller diameter of the drop, $\mathrm{D}=1.6 \mathrm{~d}$ [37]. Thus when the aerodynamic forces come into play, it results in the breakup of jet to smaller drops. Weber also studied the effect of viscosity of the liquid in jet disruption and found that increase in liquid viscosity will escalate the optimum wavelength required for breaking up the liquid jet which is given by

$$
\lambda_{\text {opt }}=4.44 \mathrm{~d}(1+3 \mathrm{Oh})^{0.5}
$$


where,

$$
\mathrm{Oh}=\sqrt{\mathrm{We}} / \operatorname{Re}=\mu_{\mathrm{L}} /\left(\rho_{\mathrm{L}} \sigma \mathrm{d}\right)^{0.5}
$$

$\mu_{\mathrm{L}}$-viscosity of the liquid

$\rho_{\mathrm{L}}$ - density of liquid

$\sigma$-surface tension

$\mathrm{Oh}-$ Ohnesorge number

We-Weber Number $=\rho \mathrm{U}^{2} \mathrm{~d} / \sigma$, $U$ is the jet velocity

Re-Reynolds Number $=\rho \mathrm{Ud} / \mu$

\subsection{Disruption of the Liquid Sheet}

The disruption of a liquid sheet into drops is similar to the breakup of a liquid jet, which is explained in the above section. When the velocity of the liquid sheet is high, the liquid generates turbulence that will actually cause the disruption of the liquid sheet, not the force exerted by the encircling air. However, when the liquid sheet comes in contact with the encircling air causes a wave disturbance in the liquid sheet and once the wavelength reaches an optimum value fragments are generated in the sheet that will contract to ligaments due to the surface tension of the liquid and ultimately broken down into droplets [30]. The relation of diameter of the drop with respect to the properties of the liquid and air is given by

$$
\mathrm{D} / \delta \propto \mathrm{We}^{-0.5}
$$

where, $\delta$ is thickness of the liquid sheet, We-Weber Number $=\rho \mathrm{U}^{2} \delta / \sigma$ and $\mathrm{U}$ is the liquid sheet velocity.

\section{Drug Delivery Applications}

There are many means to supply drugs into the human body. The conventional and the most expedient method of taking medicines is by ingestion but one limitation is that only chemically defiant materials can be distributed [61]. Inhalation is another way of delivering medicines to the human body. This is the fastest route to supply the drug into different organs through the blood circulation of the body [62]. This route of drug delivery is being widely used for the treatment of many diseases, especially for asthma, diabetes, lung disorders, cancer, etc. The target for this treatment modality is the human lungs as it can easily absorb the drug and transport it into the blood and also the drugs are not digested by the digestive enzymes, as in lungs there are low digestive enzymes [63]. Transcytosis is the mechanism through which the polypeptides and other biomolecular drugs are absorbed into the lung tissue to the blood vessels [64].

There are different types of inhalers available in the market and the most common type is, in which the medicine is available in the form of a suspension with a liquid propellant. When pressure is applied the suspension of medication is atomized into droplets in the presence of air and releases the medicine into the lungs [62]. Another one is the dry powder inhalers in which aerosols are generated in the presence of air. Table 3 briefly discusses the types of aerosol initiating techniques that are being industrially practiced. 
Table 3. Types of aerosol initiating techniques.

\begin{tabular}{|c|c|c|c|c|}
\hline Types & Applications & Advantages & Disadvantages & Ref \\
\hline $\begin{array}{l}\text { Electro hydrodynamic } \\
\text { atomization }\end{array}$ & $\begin{array}{l}\text { Bodywide delivery of } \\
\text { hypoglycemic agents }\end{array}$ & $\begin{array}{l}\text { Can control the size of } \\
\text { the drops }\end{array}$ & $\begin{array}{l}\text { Poor yield, usage of } \\
\text { electric field }\end{array}$ & [65] \\
\hline Dry powder nebulizer & $\begin{array}{l}\text { Delivery of hypochloride salt } \\
\text { of apomorphine }\end{array}$ & $\begin{array}{l}\text { Transferable, stable, free } \\
\text { of chemical substances to } \\
\text { produce pressurized air }\end{array}$ & $\begin{array}{l}\text { Larger drop size yield, } \\
\text { restricted for powdered } \\
\text { medicines, accumulation } \\
\text { in lungs }\end{array}$ & [66] \\
\hline $\begin{array}{l}\text { Pressurized metered } \\
\text { dose inhalers }\end{array}$ & $\begin{array}{c}\text { Delivery of Flovent, } \\
\text { Migranal }\end{array}$ & Transferable, manageable & $\begin{array}{l}\text { Uses chemicals to produce } \\
\text { pressurized air, accumulation } \\
\text { in upper lung }\end{array}$ & [67] \\
\hline Liquid atomization & $\begin{array}{c}\text { Delivery of Cetraxal, } \\
\text { beclometasone dipropionate, } \\
\text { Rubex }\end{array}$ & $\begin{array}{l}\text { Drug processing is } \\
\text { not essential }\end{array}$ & $\begin{array}{l}\text { Comparatively larger drops, } \\
\text { can degrade the drug, bulky }\end{array}$ & [68] \\
\hline
\end{tabular}

Depending on the energy source provided in the process and the type of atomizers used there are different types of devices that can be used in drug delivery applications. Another factor that plays a major role in the efficacy of this drug delivery system is the size of the atomized particles generated. It is observed that the atomized droplets that are used in medical applications should have a diameter less than $10 \mu \mathrm{m}$ [7]. For pulmonic applications, the size of the drops should be less than $7 \mu \mathrm{m}$ as it has to pass through the lung tissue [69]. Drug delivery applications-drop diameter should be 3-5 $\mu \mathrm{m}$ [70]; drug supply to alveoli sacs-drop diameter should be 1-3 $\mu \mathrm{m}$ [71].

Electro hydrodynamic atomization or simply electrospraying is the methodology used for a guided and continuous drug delivery by enclosing the drug in a microparticle which is mostly a biodegradable polymers [72]. In the presence of an electric field, the liquid stream is atomized to generate very fine mist [73]. Lee and his group developed a drug loaded micro/nanoparticle by utilizing the coaxial electro hydrodynamic atomization technique. The polymer they used was the poly(lactic-co-glycolic) acid (PLGA). This was developed as a core shell system in which the drug was in the core and the polymer was encapsulating the drug. The size of the particles obtained in the atomized spray were in the range of $165 \mathrm{~nm}-1.2 \mu \mathrm{m}$ with an encapsulation ability of 100\% [74]. Later, another investigation was done by the same researchers in which they encapsulated the PLGA coating on multiple drugs by employing the coaxial triple-fluid nozzle system and studied the delivery profile of the drug by comparing it with their previous study [75]. Nie et al. modified the coaxial electro hydrodynamic atomization method by incorporating two drugs, one hydrophobic and another hydrophilic in the core and shell of a microparticle. The core of the microparticle was made up of polylactic acid to which the hydrophobic drug paclitaxel was embodied and the shell was made up of PLGA polymer to which the hydrophilic drug suramin was added. They found that the release of the drugs in the above-mentioned system is subsequent, and it lasted for a period of 30 days. When the hydrophilic drug was entrapped in the core and the hydrophobic drug in the shell, they observed an aligned delivery of the drugs from the microparticles [76].

\section{Electrospray Atomization and Its Characteristics}

Electro-hydro dynamic atomization is also known as electrostatic/electrospray atomization and it is usually considered as an alternative methodology to other techniques utilizing heat and some chemical substances. Electrospray atomization is the basic principle behind electrospinning (which gives rise to fibres) and electrospray (initiating fine spray containing particles). Electrospraying is the most widely used procedure in which a very high voltage electric current is applied to influence the liquid stream coming out of an orifice to either form a cone-jet which is the most common, dripping or multi-jet and ultimately generating long fibres or small droplets based on its application [77]. Even though 
the experimental apparatus and the parameters are the same for electrospinning and electrospraying, the results obtained are different in its structure [78]. Micro/nanofibers are the result of electrospinning which has a range of applications in the field of tissue engineering [79], cancer therapy [80], antibacterial coating [81], etc. micro/nanobeads are the product of electrospraying and its application is in the field of pharmaceutics and drug delivery. Figure 5 represents the schematic of the working apparatus of both electrospinning and electrospray.

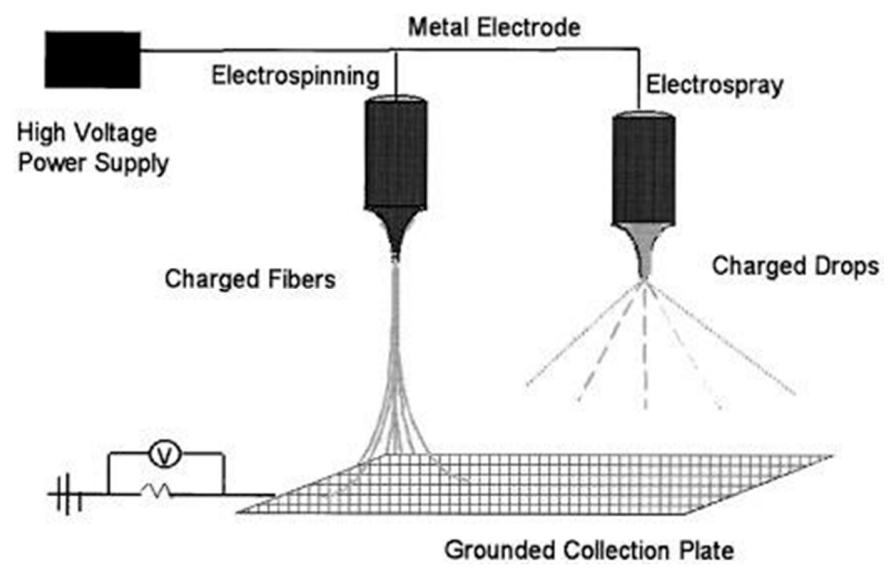

Figure 5. Schematic representation of electrospinning and electrospray; reproduced with permission from [82].

Electro hydrodynamic atomization was first studied in the year 1600 by the scientist Gilbert [83] and later Rayleigh theoretically and experimentally calculated the maximum electric charge that a liquid droplet can carry and he named it as Rayleigh limit after his name [12]. In 1960, Taylor mathematically explained the development of cone-jet in the liquid stream in the action of an electric current and the cone is known as Taylor cone [84]. Further modification in the experimental parameters lead to the development of biomolecules [85] with a range of applications in different fields.

\section{Working Principle and Components of Electrospray}

Electrospray constitutes a syringe setup with a metallic needle to which an electric current is connected from a high voltage generator. The needle of the syringe acts as an orifice through which the fluid comes out. The syringe is connected to a syringe pump with which we can apply the required pressure to push the working fluid in the syringe. There is a collector which is grounded so that the atomised drops/particles can be collected on its surface [78]. Figure 6 shows the basic components in an electrospray and also the forces acting on the Taylor cone to develop droplets.
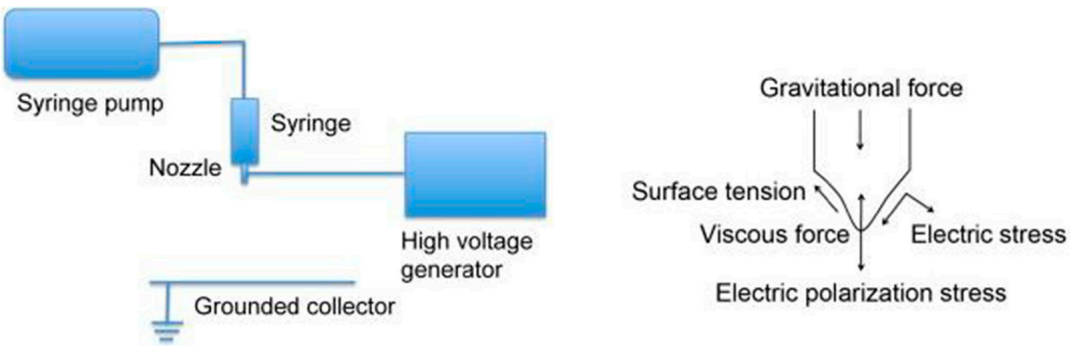

Figure 6. Components in an electrospray setup and the forces acting on Taylor cone; reproduced with permission from [86].

Sometimes the whole setup explained above will be enclosed in a chamber through which air or nitrogen will be allowed to flow continuously so that the atomized particles will 
be transported to the collector region. This also enhances the production of small, smooth and uniform droplets $[87,88]$. The forces acting on the Taylor cone are the gravitational pull which will be negligible if the viscosity of the working fluid is high, viscosity and surface tension of the fluid and the working parameter that is the electric field.

Table 4 compares electrospray to other common techniques in generating micro/nano polymeric particles applied for drug delivery applications.

Table 4. Comparing electrospray to other common techniques.

\begin{tabular}{|c|c|c|c|}
\hline Techniques & Merits & Challenges & Ref \\
\hline Electrospray & $\begin{array}{l}\text { One step process; confined particle size that is } \\
\text { micro and nanoparticles; polymers with higher } \\
\text { molecular weights can be employed; surfactant } \\
\text { free; utilizes less solvents; drugs that are slightly } \\
\text { soluble in water can be processed }\end{array}$ & $\begin{array}{l}\text { Low yield; sometimes requires cross-linking } \\
\text { factors; advancing the technique for bulk } \\
\text { manufacturing is not possible }\end{array}$ & [89] \\
\hline Spray drying & $\begin{array}{l}\text { Develops inorganic polymeric microparticles; } \\
\text { scale-up production }\end{array}$ & $\begin{array}{l}\text { Uses higher temperature gases as transporter; } \\
\text { denatures heat sensitive substances }\end{array}$ & {$[90,91]$} \\
\hline Nanoprecipitation & $\begin{array}{c}\text { Easy procedure; nanoparticles generated by } \\
\text { desorption; efficiently encloses hydrophobic } \\
\text { drugs; surfactant free }\end{array}$ & $\begin{array}{l}\text { Utilizes substantial amount of solvent; drug } \\
\text { loaded in the particles are low }\end{array}$ & {$[92]$} \\
\hline $\begin{array}{l}\text { Emulsion solvent } \\
\text { vaporization }\end{array}$ & $\begin{array}{l}\text { Adaptable technique; generates diverse } \\
\text { biomolecular particles }\end{array}$ & $\begin{array}{c}\text { Only uses low molar mass polymers; not free of } \\
\text { surfactants and solvents; not a single step } \\
\text { technique; wide range of particle size }\end{array}$ & [89] \\
\hline Sheet by sheet fabrication & $\begin{array}{l}\text { Accurate; multi-tiered particles; uniform sheet } \\
\text { thickness; regulated drug delivery }\end{array}$ & $\begin{array}{l}\text { Tiresome and lengthy process; advancing the } \\
\text { technique for bulk manufacturing is not possible }\end{array}$ & {$[93]$} \\
\hline
\end{tabular}

\section{Biomedical Applications}

Electrospray atomization can be applied in different fields like food processing, drug delivery, cell encapsulation, sensing, diagnostic and therapeutic imaging, implant coating, tissue engineering, vaccine delivery, etc. Figure 7 represents a graphical abstract of electrospraying and its different biomedical applications. Some examples for each application are discussed below.

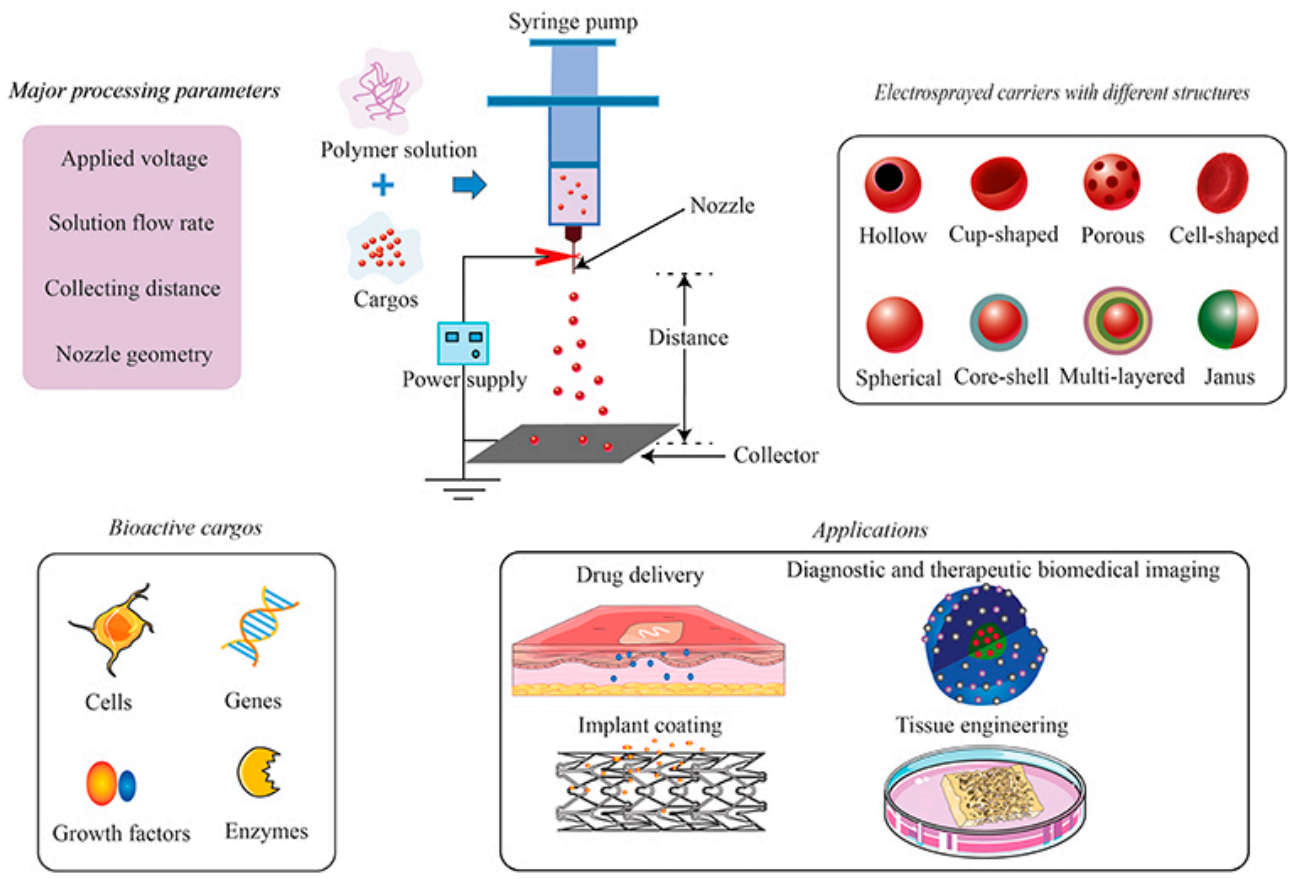

Figure 7. Graphical abstract of electrospraying and its applications; reproduced from [94]. 
In order to attain a very fine and uniform coating of chocolate, Gorty et al. studied the electro hydrodynamic atomization process on chocolate and they obtained a very thin coating of the chocolate [95]. They also studied the atomization of Theobroma oil and lauric oil in the presence of electric fields and obtained a better coverage compared with other coating techniques [96]. Ding et al. developed a microparticle using electrospray for the application of drug delivery systems. He used a hydrophobic drug, paclitaxel as the core of the system and enclosed this with a shell made up of PLGA polymer. The highlight of this study was he obtained a constant release of the drug for around 30 days [97]. Another group developed the same microparticles and was used for treating tumour cells by injecting these drug loaded particles under the skin of laboratory-bred albino nude mice. They found that the particles with a drug-loading efficiency of $20 \%$ showed a better performance and within 10 days of administration, the growth of the tumour was reduced significantly [98]. Another application of electrospraying technique is the encapsulation of cells for various purposes. Gasperini et al. developed a microparticle using the principle of electro hydrodynamic atomization, in which the core part contained the neuroblastoma rat cells which was enclosed in an alginate shell. They studied the viability and proliferation of the encapsulated cell [99]. Xie et al. encapsulated Hep G2 into the calcium alginate beads using the dripping mode of electrospray atomization. They varied the voltage applied at the syringe needle and observed variation in the size of the microparticles and also in the frequency of the working fluid to drip from the needle. When the voltage was high, the system generated smaller droplets and an increase in the dripping frequency [100]. There are different applications for the metal oxides as it is small in size and can be easily generated. One such application of metal oxides is to sense the presence of diverse gases. Electrospray is the technique used to coat metal oxides on surfaces and utilize it for the sensing application. A group of scientists coated the glass surface with a film which has different coats of tin dioxide particles and they followed the electrospray pyrolysis method to modify the glass surface. This surface was used to detect the presence of hydrogen gas and it showed significantly good ability in sensing [101]. Cusano et al. developed a similar surface in which tin dioxide was coated on silica optical fibre to detect the concentration of ammonia in water surroundings [102]. The dominance of electrospray technique compared to other techniques is that it is cost effective and convenient to use.

Scientists understood that by modifying the experimental parameters of electrospray a contrast agent or any other fluorescent dye can be incorporated along with the drugs into microparticles and this can be used for imaging the affected parts in the body. In 2015, Foroutan et al. integrated electrospray with a chemical solution deposition method to generate an imaging agent that can be used in ultrasound imaging. With this technique they developed nanospheres of ternary phosphate glass and their in vivo study revealed that these nanoparticles are not causing any cytotoxic effect to the nude mice to which the samples were injected subcutaneously [103]. Zang et al. utilized a triple needle coaxial electrospray atomization to engineer a core-shell particle to enable diagnostic imaging. The imaging agent incorporated into the shell made of polymer is the iron oxide particles and they used this for ultrasound imaging and MRI [104].

The surface modification of the implants were done using the electro hydrodynamic atomization to improve the functionality of the implants. Using the coaxial electrospray methodology, Li et al. developed a coating of microparticles with an anticoagulant in the core protected by a polymer shell on the surface of vascular surrogates. They could obtain a controlled release of heparin for about 15 days without losing the potential of heparin [105]. Another group of researchers fabricated a drug eluting stent by coating the surface of a stent with particles containing Montelukast and PLGA. They obtained a uniform and fine spherical size for particles incorporating 3\% and $6 \% w / w$ drugs and the release study showed that even though there was a primary burst of the drug, it delivered a conserved release for 40 days [106].

The biomolecular particles generated from electrospray atomization is widely applied in the field of tissue engineering especially in bone regeneration [94]. Wang et al. 
developed macromolecules by employing coaxial electrohydrodynamic atomization with a core made of PLGA and a growth factor for bone regeneration (BMP-2) and shell made of PLGA and VEGF- a growth factor enhancing angiogenesis. Since VEGF was coated in the shell, it showed a primary burst and BMP-2 showed a sequential release without affecting the bioactivity of both the growth factors [107]. In 2018, a group of scientists flourished harmless hydroxyapatite microparticles by combining sol-gel technique with electrospraying and by altering the experimental parameters they could vary the size of the particles generated. They found that in the presence of these microparticles the rat mesenchymal stem cells were differentiating to bone. They also studied the drug delivering efficiency of these particles to understand that this is a potent particle that can be used for bone tissue engineering and also as a drug delivery system [108].

It is known that the proteins and peptide molecules when encapsulated using electrospray technique in a polymeric shell, the chances of these proteins and peptides to get denatured is very less compared to other conventional methods, so this advantage has been exploited in developing a vaccine delivering machine [109]. Suksamran and his group succeeded in developing an antigen incorporated polymer biomolecules to study the immune response in mice. They generated an ovalbumin ingested chitosan particles and studied its characteristics to find that the particle generated from electrospray technique were round, smooth and uniform with a diameter of 1 to $3 \mu \mathrm{m}$. The in vitro and in vivo study showed that there was no cytotoxic effect, and the particles were orally administered into BALB-C mice. The microparticles coated with $250 \mu \mathrm{g}$ ovalbumin demonstrated the highest immune response [110]. Another group encapsulated synthetic antigen of E. coli into microparticles made of chitosan and water-soluble derivative trimethylated chitosan. These particles were directed to the BALB-C mice through the nose and the dosages were on day 1, 28 and 42. The results showed that the mice produced antibodies (IgG \& IgA) against the introduced antigen, and which was quantitatively measured using ELISA [111]. Recently scientists are working on inhaling type vaccines rather than injections for the cure of the current pandemic COVID-19. China has developed and approved clinical study of vaccines that can be inhaled, and experts say that efficiency of such vaccines need to be demonstrated in clinical experiments. Researchers are working on it to develop a much easier way of vaccination.

Thus, electrospray can be modified and optimized to take full advantage of this technique in various medical fields as it is more user friendly and cost effective compared to other conventional methods of working.

\section{Conclusions}

The study on atomization started decades ago and this has helped us to understand the complexity of the process and to exploit it in different fields. By sharply studying the topic, it is understood that atomization is simply the process of breaking down the working fluid into fine droplets. However, in order to break down the liquid into droplets, there are certain factors that come into the play of atomization. Pressure is one main factor that plays a major role in atomization. When the liquid is pressurized to flow through a small orifice, the surface tension of the liquid causes it to come out of the opening either as a jet or a sheet which then comes in contact with the surrounding air to disrupt into small droplets. This disruption of the jet or sheet is studied as primary atomization and secondary atomization. The stagnant drop formation is explained by quasi-steady state equilibrium and the modelling proposals are extracted from linear stability review. The kinetics of the liquid jet and sheet explains the instability and the process of disruption of jet or sheet into droplets. The direct development of disequilibrium on both liquid jet and sheet has been explained using simple mathematical formulations after surveying the literature. In the initial literature studies the viscosity of the fluids were not considered but later on the properties of the fluids including the viscosity of both the fluids, i.e., both working fluid and surrounding air is considered to calculate the size of the generated droplets. This has helped the researchers in understanding the fluid dynamics of liquid jet 
or sheet in the process of atomization by considering the impact of momentum contour, dimensionless quantities and the kind of disequilibrium magnification. It is also reported in literature that the disequilibrium distortion of the liquid jet and sheet into fine droplets is directly influenced by the momentum profiles and the thickness of the liquid jet or sheet.

It is studied that the size of the droplets generated from atomization depends on various factors including the liquid properties and the experimental parameters. The liquid properties include the viscosity and surface tension of the working liquid and the experimental parameters include the pressure, temperature, the type of the atomizers and the energy source. Another factor which plays an important role in droplet diameter determination and its size distribution is the ratio of the mass flow rate of gas to liquid (GLR). It can be postulated from the literature that as the GLR value is increased the energy to the droplet from the nozzle is higher which can overcome the viscous force and thereby providing an upgraded atomization feature. Even if there is a correlation between the experimental and theoretical models, further investigation will be required to understand various effects that have been expressed in the experimental data like the dip of the speed of the droplets during the downstream process of atomization which is not considered in the theoretical model.

Even though there are different types of atomization process depending on the energy source, electrohydrodynamic atomization is considered the most versatile as it generates spherical, small, uniform and homogeneous particles compared to other types. Due to its versatility, the electrohydrodynamic or electrospray atomization is widely used in different fields like food processing, drug delivery, cell encapsulation, sensing, diagnostic and therapeutic imaging, implant coating, tissue engineering and vaccine delivery. The main advantage of electrospraying is that it generates fine particles with confined size and shape and can be used for various biomedical applications. Compared to other complex techniques, this is a simple, robust and one-step process. To improve the efficiency of the technique, scientists have modified the procedure for example with needleless equipment, numerous dispersing jets, etc. One limitation with electrospraying for biomedical applications is while using organic solvents which can destroy the biological functions of the drugs, genes, cells, enzymes, etc. Recently researchers are working to improve this limitations. Thus, atomization is a potent tool, further study on it may uncover a different side which can be utilized to improve the public life.

Author Contributions: A.M. carried out the literature search, analysed and wrote the manuscript. H.L. commented and edited the manuscript. S.R. supervised the project and provided scope and directions. All authors have read and agreed to the published version of the manuscript.

Funding: Authors acknowledge the funding support from the UParis-NUS 2020 grant with IdEX code: ANR-18-IDEX-00001 and project number 2020-06-R/UP-NUS.

Institutional Review Board Statement: Not applicable.

Informed Consent Statement: Not applicable.

Data Availability Statement: Not applicable.

Conflicts of Interest: The authors declare no conflict of interest.

\section{References}

1. Lapple, C.E.; Henry, J.P.; Blake, D.E. Atomization-A Survey and Critique of the Literature; Special Report; Department of the Army: Edgewood Arsenal, MD, USA, 1967; pp. 11-14. Available online: https://apps.dtic.mil/dtic/tr/fulltext/u2/821314.pdf (accessed on 6 March 2021).

2. Graco, Atomization Concept and Theory, 1-18. Available online: http://wwwd.graco.com/training/concept_and_theory/ Atomization\%20v2.pdf (accessed on 6 March 2021).

3. Zare, M.; Zare, M.; Butler, J.A.; Ramakrishna, S. Nanoscience-Led Antimicribial Surface Engineering to Prevent Infections. ACS Appl. Nano. Mater. 2021, 4, 4269-4283. [CrossRef]

4. $\quad$ Lee, J.G.; Cho, H.J.; Huh, N.; Ko, C.; Lee, W.C.; Jang, Y.H.; Lee, B.S.; Kang, I.S.; Choi, J.W. Electrohydrodynamic (EHD) Dispensing of Nanoliter DNA Droplets for Microarrays. Biosens. Bioelectron. 2006, 21, 2240-2247. [CrossRef] 
5. Wu, Y.; Clark, R.L. Controllable Porous Polymer Particles Generated by Electrospraying. J. Colloid Interface Sci. 2007, $310,529-535$. [CrossRef]

6. Leeuwenburg, S.; Wolke, J.; Schoonman, J.; Jansen, J. Electrostatic Spray Deposition (ESD) of Calcium Phosphate Coatings. J. Biomed. Mater. Res. A 2003, 66, 330-334. [CrossRef]

7. Al-Jumaily, A.M.; Meshkinzar, A. On the Development of Focused Ultrasound Liquid Atomizers. Adv. Acoust. Vib. 2017, 1-10. [CrossRef]

8. Topp, M.N. Ultrasonic Atomization-A Photographic Study of Themechanism of Disintegration. J. Aerosol. Sci. 1973, 4, 17-25. [CrossRef]

9. Avvaru, B.; Patil, M.N.; Gogate, P.R.; Pandit, A.B. Ultrasonic atomization: Effect of liquid phase properties. Ultrasonics 2006, 44, 146-158. [CrossRef] [PubMed]

10. Marek, M.; Robert, O.; Marek, S. Comparison of the Viscous Liquids Spraying by the Oig and the Oil Configurations of an Effervescent Atomizer at Low Inlet Pressures. J. Mech. Eng. 2016, 66, 53-64. [CrossRef]

11. Benjamin, M.A.; Jensen, R.J.; Arienti, M. Review of atomization: Current knowledge and future requirements for propulsion combustors. At. Sprays 2010, 20, 485-512. [CrossRef]

12. Rayleigh, L. On the Instability of Jets. Proc. Lond. Math. Soc. 1878, 10, 4-13. [CrossRef]

13. Marmottant, P.; Villermaux, E. On spray formation. J. Fluid Mech. 2004, 498, 73-111. [CrossRef]

14. Faeth, G.M. Liquid Atomization in Multiphase Flows: A Review. In Proceedings of the 30th AIAA Fluid Dynamics Conference, Norfolk, VA, USA, 28 June-1 July 1999; pp. 1-20. [CrossRef]

15. Santos, D.; Mauricio, A.C.; Sencadas, V.; Santos, J.D.; Fernandez, M.H.; Gomes, P.S. Spray Dryin-An Overview. In BiomaterialsPhysics and Chemistry -New Edition; IntechOpen: London, UK, 2017; Chapter 2; pp. 9-35. [CrossRef]

16. Gelfand, B. Droplet breakup phenomena in flows with velocity lag. Prog. Energy Combust. Sci. 1996, 22, 201-265. [CrossRef]

17. Kennedy, J.B.; Roberts, J. Rain Ingestion in a Gas Turbine Engine. In Proceedings of the 4th ILASS Meeting, Hartford, CT, USA, 21-23 May 1990.

18. Reitz, R.D.; Bracco, F.V. Mechanism of Breakup of Round Liquid Jets. In Encyclopedia of Fluid Mechanics; Gulf Publications: Houston, TX, USA, 1986; Volume 3, pp. 223-249.

19. Liu, Z.; Reitz, R. An analysis of the distortion and breakup mechanisms of high-speed liquid drops. Int. J. Multiph. Flow 1997, 23, 631-650. [CrossRef]

20. Nicholls, J.A.; Ranger, A.A. Aerodynamic shattering of liquid drops. AIAA J. 1969, 7, 285-290. [CrossRef]

21. Reinecke, W.G.; Waldman, G.D. A Study of Drop Breakup Behind Strong Shocks with Applications to Flight. AVCO Report AVSD-0110-70-77. 1970. Available online: https://apps.dtic.mil/dtic/tr/fulltext/u2/871218.pdf (accessed on 12 March 2021).

22. Liu, Z.; Hwang, S.S.; Reitz, R.D. Breakup mechanisms and drag coefficients of high-speed vaporizing liquid drops. At. Sprays 1996, 6, 353-376. [CrossRef]

23. Godavarthi, V.; Dhivyaraja, K.; Sujith, R.I.; Panchagnula, M.V. Analysis and classification of droplet characteristics from atomizers using multifractal analysis. Sci. Rep. 2019, 9, 1-10. [CrossRef]

24. Lefebvre, A.H.; McDonell, V.G. Atomization and Sprays; CRC Press: Boca Raton, FL, USA, 2017. Available online: https: //www.routledge.com/Atomization-and-Sprays/Lefebvre-McDonell/p/book/9781498736251 (accessed on 14 March 2021).

25. Kooij, S.; Astefanei, A.; Corthals, G.L.; Bonn, D. Size distributions of droplets produced by ultrasonic nebulizers. Sci. Rep. 2019, 9, 6128. [CrossRef]

26. Lefebvre, A.H. Airblast atomization. Prog. Energy Combust. Sci. 1980, 6, 233-261. [CrossRef]

27. Faeth, G.; Hsiang, L.-P.; Wu, P.-K. Structure and breakup properties of sprays. Int. J. Multiph. Flow 1995, 21, 99-127. [CrossRef]

28. Desjardins, O.; McCaslin, J.; Owkes, M.; Brady, P. Direct numerical and large-eddy simulation of primary atomization in complex geometries. At. Sprays 2013, 23, 1001-1048. [CrossRef]

29. Ramamurthi, K.; Tharakan, T.J. Flow Transition in Swirled Liquid Sheets. AIAA J. 1998, 36, 420-427. [CrossRef]

30. Ashgriz, N. Handbook of Atomization and Sprays-Theory and Applications; Springer: Toronto, ON, Canada, 2011 ; Chapters 1 \& 3. Available online: https:/ / www.springer.com/gp/book/9781441972637 (accessed on 5 March 2021).

31. McCarthy, M.; Molloy, N. Review of stability of liquid jets and the influence of nozzle design. Chem. Eng. J. 1974, 7, 1-20. [CrossRef]

32. Bazilevskii, A.V.; Rozhkov, A.N. Dynamics of capillary breakup of elastic jets. Fluid Dyn. 2014, 49, 827-843. [CrossRef]

33. Mashayek, F.; Ashgriz, N. Instability of liquid coatings on cylindrical surfaces. Phys. Fluids 1995, 7, 2143-2153. [CrossRef]

34. Donnelly, R.J.; Glaberson, W. Experiments on the Capillary Instability of a Jet. Proc. R. Soc. Lond. A 1966, 209, 547-556. [CrossRef]

35. Goedde, E.F.; Yuen, M.C. Experiments on liquid jet instability. J. Fluid Mech. 1970, 40, 495-511. [CrossRef]

36. Vassallo, P.; Ashgriz, N. Satellite formation and merging in liquid jet breakup. Proc. R. Soc. Lond. Ser. A 1991, 433, $269-286$.

37. Weber, C. To the disintegration of a jet of liquid. ZAMM J. Appl. Math. Mech. 1931, 11, 136-154. [CrossRef]

38. Bogy, D.B. Drop Formation in a Circular Liquid Jet. Annu. Rev. Fluid Mech. 1979, 11, 207-228. [CrossRef]

39. Sirignano, W.; Mehring, C. Review of theory of distortion and disintegration of liquid streams. Prog. Energy Combust. Sci. 2000, 26, 609-655. [CrossRef]

40. Michell, J.H. On the Theory of Free Stream Lines. Philos. Trans. R. Soc. A. 1890, 181, 389-431. Available online: www.jstor.org/ stable/90572 (accessed on 15 March 2021).

41. Hagerty, W.W.; Shea, J.F. A Study of the Stability of Plane Fluid Sheets. J. Appl. Mech. 1955, 22, 509-514. 
42. Rangel, R.H.; Sirignano, W.A. The Linear and Nonlinear Shear Instability of a Fluid Sheet. Phys. Fluids 1999, 3, $2392-2400$. [CrossRef]

43. Dombrowski, N.; Fraser, R.P. A Photographic Investigation into the Disintegration of Liquid Sheets. Phil. Trans. 1954, 247, 101-130. [CrossRef]

44. Dombrowski, N.; Hasson, D.; Ward, D. Some aspects of liquid flow through fan spray nozzles. Chem. Eng. Sci. 1960, 12, 35-50. [CrossRef]

45. Dombrowski, N.; Hooper, P. The effect of ambient density on drop formation in sprays. Chem. Eng. Sci. 1962, 17, 291-305. [CrossRef]

46. Senecal, P.; Schmidt, D.; Nouar, I.; Rutland, C.; Reitz, R.; Corradini, M. Modeling high-speed viscous liquid sheet atomization. Int J. Multiph. Flow 1999, 25, 1073-1097. [CrossRef]

47. Vasilyev, A.Y.; Domrina, E.S.; Kaufman, S.V.; Maiorova, A.I. Classification of Atomization Devices. J. Phys. Conf. Ser. 2019, 1359, 012131. [CrossRef]

48. Cal, K.; Sollohub, K. Spray Drying Technique. I: Hardware and Process Parameters. J. Pharm. Sci. 2010, 99, 575-586. [CrossRef]

49. Anandharamakrishnan, C.; Ishwarya, S.P. Spray Drying Techniques for Food Ingredient Encapsulation; John Wiley \& Sons: Hoboken, NJ, USA, 2015. Available online: https:/ / onlinelibrary.wiley.com/doi/book/10.1002/9781118863985 (accessed on 16 March 2021).

50. Barbosa-Canovas, G.V.; Ortega-Rivas, E.; Juliano, P.; Yan, H. Food Powders: Physical Properties, Processing, and Functionality; Springer: Berlin/Heidelberg, Germany, 2005. [CrossRef]

51. Anandharamakrishnan, C. Handbook of Drying for Dairy Products; John Wiley \& Sons: Hoboken, NJ, USA, 2017. Available online: https:/ / onlinelibrary.wiley.com/doi/book/10.1002/9781118930526 (accessed on 8 March 2021).

52. Kooij, S.; Sijs, R.; Denn, M.M.; Villermaux, E.; Bonn, D. What Determines the Drop Size in Sprays? Phys. Rev. X 2018,8 , 031019. [CrossRef]

53. Lake, J.R. The effect of drop size and velocity on the performance of agricultural sprays. Pestic. Sci. 1977, 8, 515-520. [CrossRef]

54. Kublik, H.; Vidgren, M. Nasal delivery systems and their effect on deposition and absorption. Adv. Drug Deliv. Rev. 1998, 29, 157-177. [CrossRef]

55. Dolovich, M.B.; Dhand, R. Aerosol drug delivery: Developments in device design and clinical use. Lancet 2011, $377,1032-1045$. [CrossRef]

56. Le Brun, P.P.H.; de Boer, A.H.; Heijerman, H.G.M.; Frijlink, H.W. A Review of the Technical Aspects of Drug Nebulization. Pharm. World Sci. 2000, 22, 75-81. [CrossRef]

57. Squire, H.B. Investigation of the instability of a moving liquid film. Br. J. Appl. Phys. 1953, 4, 167-169. [CrossRef]

58. Chen, B.; Gao, D.; Li, Y.; Chen, C.; Yuan, X.; Wang, Z.; Sun, P. Investigation of the droplet characteristics and size distribution during the collaborative atomization process of a twin-fluid nozzle. Int. J. Adv. Manuf. Technol. 2020, 107, 1625-1639. [CrossRef]

59. Dalmoro, A.; Barba, A.A.; d'Amore, M. Analysis of Size Correlations for Microdroplets Produced by Ultrasonic Atomization. Sci. World J. 2013, 1-8. [CrossRef]

60. Poozesh, S.; Akafuah, N.K.; Campbell, H.R.; Bashiri, F.; Saito, K. Experimental and Mathematical Tools to Predict Droplet Size and Velocity Distribution for a Two-Fluid Nozzle. Fluids 2020, 5, 231. [CrossRef]

61. Pauletti, G.M.; Gangwar, S.; Knipp, G.T.; Nerurkar, M.M.; Okumu, F.W.; Tamura, K.; Siahaan, T.J.; Borchardt, R.T. Structural requirements for intestinal absorption of peptide drugs. J. Control. Release 1996, 41, 3-17. [CrossRef]

62. Ciach, T.; Diaz, L.; Ijssel, E.V.D.; Marijnissen, J.C.M. Application of Electro Hydro Dynamic Atomisation in the Production of Engineered Drug Particles. Optim. Aerosol Drug Deliv. 2003, 189-204. [CrossRef]

63. Adjei, L.; Gupta, P. Inhalation Delivery of Therapeutic Peptides and Proteins. Pharm. Res. 1997, 15, $301-313$.

64. Banker, G.S.; Rodhes, C.T. Modern Pharmaceutics; Marcel Dekker: New York, NY, USA, 2002.

65. Gomez, A. The electrospray and its application to targeted drug inhalation. Respir. Care 2002, 47, 1419-1431. [PubMed]

66. Tobyn, M.; Staniforth, J.N.; Morton, D.; Harmer, Q.; Newton, M.E. Active and Intelligent Inhaler Device Development. Int. J. Pharm. 2004, 277, 31-37. [CrossRef]

67. Shrewsbury, S.B.; Cook, R.O.; Taylor, G.; Edwards, C.; Ramadan, N.M. Safety and Pharmacokinetics of Dihydroergotamine Mesylate Administered Via a Novel (TempoTM) Inhaler. Headache 2007, 48, 355-367. [CrossRef] [PubMed]

68. Conley, J.; Yang, H.; Wilson, T.; Blasetti, K.; Di Ninno, V.; Schnell, G.; Wong, J.P. Aerosol delivery of liposome-encapsulated ciprofloxacin: Aerosol characterization and efficacy against Francisella tularensis infection in mice. Antimicrob. Agents Chemother. 1997, 41, 1288-1292. [CrossRef]

69. Hettiarachchi, K.; Talu, E.; Longo, M.L.; Dayton, P.A.; Lee, A.P. On-chip generation of microbubbles as a practical technology for manufacturing contrast agents for ultrasonic imaging. Lab Chip 2007, 7, 463-468. [CrossRef] [PubMed]

70. Patton, J.S.; Byron, P.R. Inhaling medicines: Delivering drugs to the body through the lungs. Nat. Rev. Drug Discov. 2007, 6, 67-74. [CrossRef]

71. Heyder, J. Deposition of Inhaled Particles in the Human Respiratory Tract and Consequences for Regional Targeting in Respiratory Drug Delivery. Proc. Am. Thorac. Soc. 2004, 1, 315-320. [CrossRef]

72. Davoodi, P.; Feng, F.; Xu, Q.; Yan, W.-C.; Tong, Y.W.; Srinivasan, M.; Sharma, V.K.; Wang, C.-H. Coaxial electrohydrodynamic atomization: Microparticles for drug delivery applications. J. Control. Release 2015, 205, 70-82. [CrossRef]

73. Bock, N.; Dargaville, T.; Woodruff, M. Electrospraying of polymers with therapeutic molecules: State of the art. Prog. Polym. Sci. 2012, 37, 1510-1551. [CrossRef] 
74. Lee, Y.H.; Mei, F.; Bai, M.Y.; Zhao, S.; Chen, D.R. Release Profile Characteristics of Biodegradable-polymer-coated Drug Par-ticles Fabricated by Dual-Capillary Electrospray. J. Control Release 2010, 145, 58-65. [CrossRef]

75. Lee, Y.-H.; Bai, M.-Y.; Chen, D.-R. Multidrug encapsulation by coaxial tri-capillary electrospray. Colloids Surf. B 2011, 82, 104-110. [CrossRef]

76. Nie, H.; Dong, Z.; Arifin, D.Y.; Hu, Y.; Wang, C.-H. Core/shell microspheres via coaxial electrohydrodynamic atomization for sequential and parallel release of drugs. J. Biomed. Mater. Res. Part A 2010, 95, 709-716. [CrossRef]

77. Chen, C.; Liu, W.; Jiang, P.; Hong, T. Coaxial Electrohydrodynamic Atomization for the Production of Drug-loaded Micro/Nanoparticles. Micromachines 2019, 10, 125. [CrossRef] [PubMed]

78. Jitendra, M.A.; Dutta, S.; Jitendra, M.A. Application of Electrospray Atomization (EA): A Review Article. Chem. Sci. Rev. Lett. 2018, 7, 745-750. Available online: https://chesci.com/wp-content/uploads/2018/09/V7i27_6_CS172049051_Samit_745-750.pdf (accessed on 9 March 2021).

79. Rahmati, M.; Mills, D.K.; Urbanska, A.M.; Saeb, M.R.; Venugopal, J.R.; Ramakrishna, S.; Mozafari, M. Electrospinning for tissue engineering applications. Prog. Mater. Sci. 2021, 117, 100721. [CrossRef]

80. Abid, S.; Hussain, T.; Raza, Z.A.; Nazir, A. Current applications of electrospun polymeric nanofibers in cancer therapy. Mater. Sci. Eng. C 2019, 97, 966-977. [CrossRef] [PubMed]

81. Soo, J.Z.; Chai, L.C.; Ang, B.C.; Ong, B.H. Enhancing the Antibacterial Performance of Titanium Dioxide Nanofibers by Coating with Silver Nanoparticles. ACS Appl. Nano Mater. 2020, 3, 5743-5751. [CrossRef]

82. Deitzel, J.; Kleinmeyer, J.; Harris, D.; Tan, N.B. The effect of processing variables on the morphology of electrospun nanofibers and textiles. Polymer 2001, 42, 261-272. [CrossRef]

83. Gilbert, W. Gilbert's Book on Magnets, De Magnete, Londini, Anno MDC. 1600. Available online: https:/ /www.sciencephoto. com/media/765107/view/gilbert-s-book-on-magnets-1600 (accessed on 18 March 2021).

84. Taylor, G. The Force Exerted by an Electric Field on a Long Cylindrical Condutor. Proc. Royal Soc. A 1966, 291, 145-158. [CrossRef]

85. Grayson, M.A. John Bennett Fenn: A Curious Road to the Prize. J. Am. Soc. Mass Spectrom. 2011, 22, 1301-1308. [CrossRef]

86. Xie, J.; Jiang, J.; Davoodi, P.; Srinivasan, M.P.; Wang, C.H. Electrohydrodynamic Atomization: A Two-decade Effort to Produce and Process Micro-/Nanoparticulate Materials. Chem. Eng. Sci. 2015, 125, 32-57. [CrossRef]

87. Xie, J.; Lim, L.K.; Phua, Y.; Hua, J.; Wang, C.-H. Electrohydrodynamic atomization for biodegradable polymeric particle production. J. Colloid Interface Sci. 2006, 302, 103-112. [CrossRef]

88. Xie, J.; Ng, W.J.; Lee, L.Y.; Wang, C.H. Encapsulation of Protein Drugs in Biodegradable Microparticles by Coaxial Electrospray. J. Colloid Interface Sci. 2008, 317, 469-476. [CrossRef]

89. Hernandez, J.A.T.; Chavez, P.I.T.; Wong, B.R.; Chu, A.R.; Jatomea, M.P.; Urbina, C.G.B.; Vazquez, N.A.R.; Felix, F.R. Micro and Nanoparticles by Electrospray: Advances and Applications in Foods. J. Agric. Food Chem. 2015, 63, 4699-4707. [CrossRef]

90. Ré, M.-I. Formulating Drug Delivery Systems by Spray Drying. Dry. Technol. 2006, 24, 433-446. [CrossRef]

91. Peltonen, L.; Valo, H.; Kolakovic, R.; Laaksonen, T.; Hirvonen, J. Electrospraying, Spary Drying and Related Techniques for Production and Formulation of Drug Nanoparticles. Expert Opin. Drug Deliv. 2010, 7, 705-719. [CrossRef]

92. Bilati, U.; Allémann, E.; Doelker, E. Development of a nanoprecipitation method intended for the entrapment of hydrophilic drugs into nanoparticles. Eur. J. Pharm. Sci. 2005, 24, 67-75. [CrossRef]

93. Hammond, P.T. Building biomedical materials layer-by-layer. Mater. Today 2012, 15, 196-206. [CrossRef]

94. Wang, J.; Jansen, J.A.; Yang, F. Electrospraying: Possibilities and Challenges of Engineering Carriers for Biomedical ApplicationsA Mini Review. Front. Chem. 2019, 7, 1-9. [CrossRef]

95. Gorty, A.; Barringer, S. Electrohydrodynamic spraying of chocolate. J. Food Process. Preserv. 2011, 35, 542-549. [CrossRef]

96. Marthina, K.; Barringer, S.A. Confectionery Coating with an Electrohydrodynamic (EHD) System. J. Food Sci. 2011, 77, E26-E31. [CrossRef] [PubMed]

97. Ding, L.; Lee, T.; Wang, C.-H. Fabrication of monodispersed Taxol-loaded particles using electrohydrodynamic atomization. J. Control. Release 2005, 102, 395-413. [CrossRef] [PubMed]

98. Naraharisetti, P.K.; Ong, B.Y.S.; Xie, J.W.; Lee, T.K.Y.; Wang, C.H.; Sahinidis, N.V. In vivo Performance of Implantable Biodegradable Preparations Delivering Paclitaxel and Etanidazole for the Treatment of Glioma. Biomaterials 2007, $28,886-894$. [CrossRef]

99. Gasperini, L.; Maniglio, D.; Migliaresi, C. Microencapsulation of cells in alginate through an electrohydrodynamic process. J. Bioact. Compat. Polym. 2013, 28, 413-425. [CrossRef]

100. Xie, J.; Wang, C.-H. Electrospray in the dripping mode for cell microencapsulation. J. Colloid Interface Sci. 2007, 312, 247-255. [CrossRef]

101. Matsushima, Y.; Yamazaki, T.; Maeda, K.; Suzuki, T. Fabrication of SnO2 Particle-Layers using the Electrospray Method and Gas Sensing Properties for H2. J. Electroceram. 2004, 13, 765-770. [CrossRef]

102. Cusano, A.; Consales, M.; Pisco, M.; Pilla, P.; Cutolo, A.; Buosciolo, A.; Viter, R.; Smyntyna, V.; Giordano, M. Optochemical sensor for water monitoring based on $\mathrm{SnO} 2$ particle layer deposited onto optical fibers by the electrospray pyrolysis method. Appl. Phys. Lett. 2006, 89, 111103. [CrossRef]

103. Foroutan, F.; Jokerst, J.V.; Gambhir, S.S.; Vermesh, O.; Kim, H.-W.; Knowles, J.C. Sol-Gel Synthesis and Electrospraying of Biodegradable $\left(\mathrm{P}_{2} \mathrm{O}_{5}\right) 55-(\mathrm{CaO}) 30-\left(\mathrm{Na}_{2} \mathrm{O}\right) 15$ Glass Nanospheres as a Transient Contrast Agent for Ultrasound Stem Cell Imaging. ACS Nano 2015, 9, 1868-1877. [CrossRef] [PubMed] 
104. Zhang, C.; Yao, Z.-C.; Ding, Q.; Choi, J.; Ahmad, Z.; Chang, M.-W.; Li, J.-S. Tri-Needle Coaxial Electrospray Engineering of Magnetic Polymer Yolk-Shell Particles Possessing Dual-Imaging Modality, Multiagent Compartments, and Trigger Release Potential. ACS Appl. Mater. Interfaces 2017, 9, 21485-21495. [CrossRef] [PubMed]

105. Li, C.; Wang, F.; Ge, P.; Mao, Y.; Wang, L. Anti-acute thrombogenic surface using coaxial electrospraying coating for vascular graft application. Mater. Lett. 2017, 205, 15-19. [CrossRef]

106. Zamani, M.; Prabhakaran, M.P.; Varshosaz, J.; Mhaisalkar, P.S.; Ramakrishna, S. Electrosprayed Montelukast/poly (lac-tic-coglycolic acid) Particle Based Coating: A New Therapeutic Approach Towards the Prevention of Instent Restenosis. Acta Biomater. 2016, 42, 316-328. [CrossRef] [PubMed]

107. Wang, Y.; Wei, Y.; Zhang, X.H.; Xu, M.M.; Liu, F.; Ma, Q.; Cai, Q.; Deng, X. PLGA/PDLLA Core-Shell Submicron Spheres Se-quential Release System: Preparation, Characterization and Promotion of Bone Regeneration In vitro and In vivo. Chem. Eng. J. 2015, 273, 490-501. [CrossRef]

108. Venkatesan, Y.C.; Kumar, T.S.S.; Raj, D.K.; Kumary, T.V. Osteogenic apatite particles by sol-gel assisted electrospraying. J. Biomed. Mater. Res. Part B 2018, 106, 1941-1954. [CrossRef]

109. Steipel, R.T.; Gallovic, M.D.; Batty, C.J.; Bachelder, E.M.; Ainslie, K.M. Electrospray for generation of drug delivery and vaccine particles applied in vitro and in vivo. Mater. Sci. Eng. C 2019, 105, 110070. [CrossRef]

110. Suksamran, T.; Ngawhirunpat, T.; Rojanarata, T.; Sajomsang, W.; Pitaksuteepong, T.; Opanasopit, P. Methylated N-(4-N,Ndimethylaminocinnamyl) chitosan-coated electrospray OVA-loaded microparticles for oral vaccination. Int. J. Pharm. 2013, 448, 19-27. [CrossRef]

111. Doavi, T.; Mousavi, S.L.; Kamali, M.; Amani, J.; Ramandi, M.F. Chitosan-Based Intranasal Vaccine against Escherichia coli O157:H7. Iran. Biomed. J. 2016, 20, 97-108. 